\title{
Oxidative stability, fatty acid composition and health lipid indices of Longissimus dorsi muscle from Aberdeen Angus steers produced in different feeding systems
}

\begin{abstract}
Alejandra Terevinto ${ }^{1 *}$ María Cristina Cabrera ${ }^{1,2}$ (iD) Ali Saadoun ${ }^{1,2}$ (D)
${ }^{1}$ Departamento de Producción Animal \& Pasturas, Laboratorio Calidad de Alimentos, Facultad de Agronomía, Universidad de la República (UDELAR), Av. Garzón 809, 12900, Montevideo, Uruguay. E-mail: alejandraterevinto@gmail.com. *Corresponding author. ${ }^{2}$ Sección Fisiología \& Nutrición, Facultad de Ciencias, Universidad de la República (UDELAR), Iguá, 4225, Montevideo, Uruguay.

ABSTRACT: The aim of this study was to evaluate the oxidative and anti-oxidative status of unaged and aged Longissimus dorsi (LD) muscle obtained from a commercial abattoir. Also, fatty acid composition and calculated health lipid indices of meat were compared. Animals slaughtered were Aberdeen Angus steers raised in three typical feeding systems of Uruguay: (1) Pasture (n=10), (2) Pasture + Supplement $(P+S)$ with corn grain $(n=10)$, and (3) Feedlot $(n=10)$. Feeding had no effect on lipid and protein oxidation but the antioxidant enzymes activities were affected as follows: superoxide dismutase (SOD): Pasture, Feedlot $>P+S$; catalase: Pasture $>$ P $+S$, Feedlot; glutathione peroxidase (GPx): Feedlot $>P+S>$ Pasture. Total antioxidant potential, determined by Fenton reaction, was higher in aged meat from Pasture compared with aged meat from Feedlot. Meat from Pasture and $P+S$ presented a higher eicosapentaenoic acid (EPA), docosahexaenoic acid (DHA) and total n-3 content and a lower lipid content, n-6/n-3 ratio and trombogenic index compared to meat from Feedlot. In conclusion, Pasture seems to produce a more resistant meat against induced oxidation processes, particularly after ageing, and a healthier meat together with meat from $P+S$ system, regarding fatty acid composition and lipid indices, compared to Feedlot.

Key words: beef meat, pasture, feedlot, oxidative stability, antioxidant enzyme, fatty acid.
\end{abstract}

Estabilidade oxidativa, composição em ácidos graxos e índices lipídicos de saúde do músculo Longissimus dorsi de novilhos Aberdeen Angus produzidos em diferentes sistemas de alimentação

RESUMO: $O$ objetivo deste estudo foi avaliar o estado oxidativo e antioxidante do músculo Longissimus dorsi (LD), sem maturação e amadurecido, obtido de um matadouro comercial. Também foram comparados a composição de ácidos graxos e os índices lipídicos de saúde da carne calculados. Os animais abatidos foram os novilhos Aberdeen Angus criados em três sistemas alimentares típicos do Uruguai: (1) Pastagem ( $n=10)$, (2) Pastagem + Suplemento $(P+S)$ com grão de milho $(n=10)$, e (3) Confinamento $(n=10)$. A alimentação não teve efeito sobre a oxidação lipídica e protéica, mas as atividades das enzimas antioxidantes foram afetadas da seguinte forma: superóxido dismutase (SOD): Pastagem, Confinamento $>P+S$; catalase: Pastagem $>P+S$, Confinamento; glutationa peroxidase (GPx): Confinamento $>P+S>$ Pastagem. O potencial antioxidante total, determinado pela reação de Fenton, foi maior em carne de Pastagem amadurecida em comparação com a carne amadurecida do Confinamento. Carne de Pastagem e P + S apresentaram maior conteúdo de EPA, DHA e n-3, e menor conteúdo lipídico, razão n-6 / n-3 e índice trombogênico em comparação à carne de Confinamento. Em conclusão, o sistema Pastagem parece produzir uma carne mais resistente contra processos de oxidação induzido, particularmente após o maturação e uma carne mais saudável, juntamente com carne do sistema $P+S$, em relação à composição de ácidos graxos e índices lipídicos, comparado com o sistema Confinamento. Palavras-chave: carne bovina, pastagem, confinamento, estabilidade oxidative, enzima antioxidante, ácido graxo.

\section{INTRODUCTION}

During handling, processing and storage of meat, oxidation processes induces modifications of muscle lipids and proteins and; therefore, affects the organoleptic and nutritional properties of meat and meat products (INSANI et al., 2008). Lipid oxidation in muscle foods is initiated by stressors arising from both internal and external sources. The most important stressors are the reactive oxygen species (ROS) including free radicals and peroxides
(DESCALZO et al., 2005). Protein oxidation is responsible for many biological modifications as protein fragmentation or aggregation and decrease in protein solubility, which affects the quality of meat and meat products (MERCIER et al., 2004). Conversely, the oxidative stability of meat depends upon balance between anti- and pro-oxidants and composition of oxidation substrates including polyunsaturated fatty acids (PUFA), cholesterol, proteins and pigments (GATELLIER et al., 2004). Meat produced on pasture or grain differs in their antioxidants, pro-oxidants and 
fatty acids composition (DESCALZO et al., 2008). Pasture feeding increases PUFA in beef compared with grain feeding, and lipids containing PUFA are particularly prone to attack by free radicals.

Moreover, grass, in pasture feeding, is particularly rich in natural antioxidants such as vitamins $\mathrm{A}, \mathrm{C}$ and especially $\mathrm{E}$ and phytochemicals such as carotenoids and flavonoids, and so offers a great protection against lipid oxidation (GATELLIER et al, 2004). All these natural antioxidants act as chain breaking in radical production and are considered as a second line of protection against radical attack (GATELLIER et al, 2004). The antioxidant enzymes superoxide dismutase (SOD), catalase and glutathione peroxidase (GPx) constitute the primary mechanism for protecting cells from oxidative damage in vivo (DESCALZO et al., 2005). These antioxidant enzymes are relatively stable in beef meat during refrigerated storage, so they can offer some time post-mortem, a protection against free radical damage (GATELLIER et al., 2004).

In Uruguay, beef cattle production systems are based mainly on pasture feeding, but recently livestock producers have been investing on improved pastures and supplementation with grains leading to cattle with different carcass and meat quality attributes (REALINI et al, 2009). There is some recent information about beef meat quality concerning oxidative stability and nutritional value, such as fatty acid and mineral composition (CABRERA \& SAADOUN, 2014; REALINI et al., 2004) of these different kinds of meat produced in Uruguay. Informed consumers generally consider meat finished on pasture healthier than meat finished on grains (CABRERA \& SAADOUN, 2014; VAN ELSWYK \& MCNEILL, 2014). This is probably related to the link between the fatty acid composition of meat and the occurrence of cardiovascular diseases (SIMOPOULOS, 2002). However, there is limited scientific evidence which supports this concept for meat produced in Uruguay. For this reason, the objective of this study was to compare commercial meat obtained from the three different feeding systems that take place in Uruguay (Pasture, Pasture plus grain supplementation and Feedlot), evaluating its oxidative stability and fatty acid composition.

\section{MATERIALS AND METHODS}

Meat samples and animal diets

For this study, the Longissimus dorsi (LD) muscle from ten steers of each feeding system (Pasture, Pasture + Supplement and Feedlot) were obtained from the Solis abattoir (BPU-NH group). Animals (24-30 months old) coming from a larger herd from each of the three commercial farms, were randomly selected and certified Aberdeen Angus by the Aberdeen Angus Society (Uruguay) in the abattoir. The time and conditions of transport, and lairage time in abattoir have been especially ensured to be similar for the three groups of animals. Animals have been raised in three different feeding systems established for meat export in Uruguay: (1) Pasture $(\mathrm{n}=10)$, produced on natural and improved pastures during the last 130 days before slaughtering (mean live weight at slaughtering $479.8 \mathrm{~kg})$; (2) Pasture + Supplement $(\mathrm{n}=10)$, fed natural and improved pastures, the same as in Pasture system, and supplemented ad libitum with corn grain during the last month before slaughtering (mean live weight at slaughtering $497.4 \mathrm{~kg}$ ); (3) Feedlot (n=10), fed with natural and improved pastures, the same as in Pasture system and afterwards a diet with roughage to concentrate ratio of 30:60 (on dry matter basis) during the last 90 days before slaughtering (mean live weight at slaughtering $502.4 \mathrm{~kg}$ ). For Pasture, Pasture + Supplement and Feedlot systems, pasture consisted of tall fescue (Festuca arundinacea), white clover (Trifolium repens) and birds foot trefoil (Lotus subbiflorus). For Feedlot system roughage consisted of whole plant sorghum silage and silo wet grain sorghum, and concentrate ration consisted of soybean hulls and wheat bran, minerals sources, urea and ionophore.

Animals were slaughtered the same day in an authorized abattoir following rules of Ministry of Agriculture of Uruguay (MGAP). After 36 hours postmortem of carcasses chilling, the LD muscle was removed from each left half carcass and divided in two pieces of approximately $500 \mathrm{~g}$ each. One piece was vacuum packed and aged at $1-2{ }^{\circ} \mathrm{C}$ for 14 days (aged meat) and then frozen at $-20{ }^{\circ} \mathrm{C}$ until further analysis, and the other piece was vacuum packed (unaged meat) and then frozen at $-20{ }^{\circ} \mathrm{C}$ until further analysis. The LD was selected for this study because it is the main muscle of striploin, which is a high commercial value cut for beef meat export.

\section{Determination of lipid oxidation}

Lipid oxidation was determined for unaged and aged meat samples kept frozen at $-20{ }^{\circ} \mathrm{C}$, from steers produced in the three feeding systems, following the methodology of TBARS (thiobarbituric acid reactive species) described by LYNCH \& FREI (1993) and GATELLIER et al. (2004). Briefly, $10 \mathrm{~g}$ of frozen meat were homogenized in a Waring-Blender (Fisher Inc. USA) with $200 \mathrm{ml}$ of an extraction buffer $(0.15 \mathrm{M} \mathrm{KCl}, 0.02 \mathrm{M}$ EDTA and $0.30 \mathrm{BHT})$ at 12,000

Ciência Rural, v.49, n.12, 2019. 
rpm for $1 \mathrm{~min}$. Samples were centrifuged (Sorvall ST16-R, USA) at $2000 \times \mathrm{g}$ for $10 \mathrm{~min}$ at $4{ }^{\circ} \mathrm{C}$ and $1 \mathrm{ml}$ of the supernatant was incubated with $1 \mathrm{ml}$ of 2TBA- TCA solution (35 mM TBA and 10\% TCA in $125 \mathrm{mM} \mathrm{HCl}$ ) in a boiling water bath for $30 \mathrm{~min}$. The reaction was stopped by placing tubes in an ice bath and then were left at room temperature for $45 \mathrm{~min}$. A $3 \mathrm{ml}$ of n-butanol was added, centrifuged for $10 \mathrm{~min}$ at $3000 \mathrm{x} g$ and the absorbance of the supernatant was measured at $535 \mathrm{~nm}$. Results were expressed as $\mathrm{mg}$ $\mathrm{MDA} / \mathrm{kg}$ of meat and the molar extinction coefficient of the malondialdehyde (MDA, 156,000 $\mathrm{M}^{-1} \mathrm{~cm}^{-1}$ ) was used to calculate the concentration of MDA.

\section{Determination of protein oxidation}

Protein oxidation was determined for unaged and aged meat samples from steers produced in the three feeding systems, following the carbonyl protein assay described by MERCIER et al. (2004), using the same homogenate that was used for TBARS test, frozen the day before. After the samples were thawed, two aliquots of $2 \mathrm{ml}$ were put in two different tubes. One was incubated with $2 \mathrm{ml}$ of 2 $\mathrm{M} \mathrm{HCl}$ (blank) and the other with $2 \mathrm{ml}$ of $0.02 \mathrm{M}$ dinitrophenylhydrazine (DNPH) in $2 \mathrm{M} \mathrm{HCl}$. After one hour of incubation with regular stirring, $2 \mathrm{ml}$ of $20 \%$ TCA was added and left 15 min with regular stirring. Centrifugation was done for $10 \mathrm{~min}$ at 2000 $\mathrm{x} g$ and the pellets were washed with $4 \mathrm{ml}$ ethanol: ethyl acetate (1:1) for three times. After each wash, centrifugation was done at $2000 \mathrm{x} g$ for $10 \mathrm{~min}$.

Pellets were dissolved in $6 \mathrm{ml}$ of $6 \mathrm{M}$ $\mathrm{HCl}$ with $0.02 \mathrm{M} \mathrm{KH}_{2} \mathrm{PO}_{4}(\mathrm{pH} 6.5)$. After $15 \mathrm{~min}$ of regular stirring, the tubes were centrifuged for $10 \mathrm{~min}$ at $2400 \times \mathrm{g}$, and the supernatant absorbance was measured at $370 \mathrm{~nm}$. The expression of results was as $\mathrm{n}$ moles of $\mathrm{DNPH} / \mathrm{mg}$ of protein. DNPH concentration was calculated using the DNPH molar extinction coefficient $\left(22,000 \mathrm{M}^{-1} \mathrm{~cm}^{-1}\right)$ and protein content was determined at $280 \mathrm{~nm}$ using bovine serum albumin (BSA) (Sigma chemicals, USA) as protein standard, following the method described by STOSCHECK (1990).

\section{Determination of antioxidant enzymes activities}

Activity of the three antioxidant enzymes was determined for unaged and aged meat samples that were kept frozen at $-20{ }^{\circ} \mathrm{C}$, from steers produced in the three feeding systems $(n=10)$. Total SOD activity was determined measuring the inhibition of pyrogallol autoxidation at $340 \mathrm{~nm}$ and results were expressed as IU/g meat, where one unit (IU) was taken as the activity that inhibits the reaction by $50 \%$.
Catalase activity was measured recording the $\mathrm{H}_{2} \mathrm{O}_{2}$ disappearance at $240 \mathrm{~nm}$ and results were expressed as $\mathrm{n}$ moles of discomposed $\mathrm{H}_{2} \mathrm{O}_{2} / \mathrm{min} / \mathrm{mg}$ protein, using the molar extinction coefficient of $\mathrm{H}_{2} \mathrm{O}_{2}\left(39.4 \mathrm{M}^{-1} \mathrm{~cm}^{-1}\right)$.

The GPx activity was measured recording the oxidation of $\beta$-nicotinamide adenine dinucleotide 2 '-phosphate reduced tetrasodium salt hydrate (NADPH) at $340 \mathrm{~nm}$ and an extinction coefficient of $6300 \mathrm{M}^{-1} \mathrm{~cm}^{-1}$ was used to calculate NADPH concentration. Results were expressed as n moles of oxidized NADPH/min/mg protein. Methodologies to measure the three antioxidant enzymes activities were previously described in TEREVINTO et al. (2010). To express catalase and GPx activities results, protein content was determined at $280 \mathrm{~nm}$ using BSA (Sigma chemicals, USA) as protein standard, following the method described by STOSCHECK (1990).

\section{Determination of antioxidant potential}

The antioxidant potential was measured for unaged and aged meat samples that were kept frozen at $-20{ }^{\circ} \mathrm{C}$, from steers produced in the three feeding systems, using the in vitro iron-induced lipid oxidation (Fenton reaction) method described in TEREVINTO et al. (2010). Results were expressed as $\mathrm{mg} \mathrm{MDA} / \mathrm{kg}$ meat.

\section{Determination of total lipid content and fatty acid composition}

The intramuscular fat was extracted from unaged meat samples, that were kept vacuum and frozen at $-20{ }^{\circ} \mathrm{C}$, following the procedure of FOLCH et al. (1957) described in DEL PUERTO et al. (2017). A $4 \mathrm{~g}$ of meat were cut into small pieces and then homogenized in a Virtis 45 with $100 \mathrm{ml}$ chloroform: methanol (2:1). Dry lipids contained in glass balloons (after chloroform evaporation, storage in desiccator in vacuum and protected from light and weighed) were dissolved in hexane p. a. (pure for analysis). Immediately after, lipids were submitted to the methylation process according to ICHIHARA et al. (1996) using methanolic potassium hydroxide $(\mathrm{KOH})$.

Fatty acid analysis was performed by gas chromatography following the procedure described by EDER (1995) and a fused-silica CPSIL-88 capillary column of $100 \mathrm{~m}$ installed in a split/splitless chromatograph Clarus 500 (Perkin Elmer Instruments, USA) was used. Hydrogen was used as carrier gas at a flow rate of $1 \mathrm{ml} / \mathrm{min}$ and a FID detector was used with a mixture $\mathrm{H}_{2} / \mathrm{O}_{2}$ at a flow rate of $30 \mathrm{ml} / 300 \mathrm{ml}$ by minute. Fatty acids (FAMEs) were determined comparing the retention time to fatty acids standards 
(Sigma Corp, USA). Each FAME was quantified as a percentage of total detected FAMEs.

\section{Calculation of health lipid indices}

Calculations of lipid indices were performed from the data of the fatty acid composition of meat. The atherogenic index (AI) was calculated as $\left[\mathrm{C} 12: 0+4^{*}(\mathrm{C} 14: 0)+\mathrm{C} 16: 0\right] /[(\Sigma \mathrm{PUFA})+(\Sigma \mathrm{MUFA})]$ and indicated the relationship between the sum of the main saturated (proatherogenic) and the unsaturated (antiatherogenic) fatty acids. The thrombogenic index (TI) was calculated as [C14:0+C16:0+C18:0]/ $\left[\left(0.5^{*} \Sigma\right.\right.$ MUFA $\left.)+\left(0.5^{*} n-6\right)+\left(3^{*} n-3\right)+(n-3 / n-6)\right]$ and estimates the potential to form clots in the blood vessels, determined by the relationship between the prothrombogenic (saturated) and the antithrombogenic fatty acids (sum of MUFA and PUFA). Both indices were calculated as described by ULBRICHT \& SOUTHGATE (1991). The hypocholesterolemic/hypercholesterolemic ratio $(\mathrm{h} / \mathrm{H})$ was based on calculus from FERNÁNDEZ et al. (2006), and were as follows: $(\mathrm{C} 14: 1+\mathrm{C} 16: 1+\mathrm{C} 18$ : $1+\mathrm{C} 20: 1+\mathrm{C} 22: 1+\mathrm{C} 18: 2+\mathrm{C} 18: 3+\mathrm{C} 20: 3+\mathrm{C} 20: 4+\mathrm{C} 20$ : $5+\mathrm{C} 22: 4+\mathrm{C} 22: 5+\mathrm{C} 22: 6) /(\mathrm{C} 14: 0+\mathrm{C} 16: 0)$.

\section{Statistical analysis}

Results were reported as means \pm standard error of the media (SEM). Effects of feeding system and aging on the TBARS, carbonyl content, SOD, catalase and GPx activities data were analyzed by ANOVA using the General Linear Model (GLM) procedure (NCSS software release 2007, 329 North 1000 East, Kaysville, UT 84037). To analyze the effects of feeding system and incubation time on ironinduced lipid oxidation data, a repeated measures ANOVA was followed for unaged and for aged meat. At each incubation time, TBARS data of different feeding systems were compared using a one-way ANOVA followed by the Tukey-Kramer multiple comparison test, in unaged and in aged meat.

To analyze the feeding system effect on total lipid content, fatty acid composition and health lipid indices data, a one-way ANOVA followed by the Tukey-Kramer test was made. In all the analysis, the level of significance was established at $P<0.05$.

\section{RESULTS AND DISCUSSION}

\section{Lipid and protein oxidation}

When lipid oxidation was measured in meat samples, no feeding system effect was observed $(\mathrm{P}=0.087)$ (Table 1). PUFA are the main target of oxidation process in meat (GATELLIER et al., 2004), but in this research no differences between feeding systems in meat total PUFA content was observed (Table 3). Despite this, a higher PUFA n-3 content in meat from Pasture and $P+S$ was observed, compared with meat from Feedlot (Table 3). In other reported investigations, it was reported a higher lipid oxidation in LD muscle of grain fed steers compared with those fed on Pasture (GATELLIER et al., 2005; REALINI et al., 2004), in Charolais and Hereford breeds, respectively. Thus, a breed effect cannot be ruledout to explain the differences between our results and those of other authors. However, ageing had an effect on lipid oxidation $(P<0.001)$, where aged meat

Table 1 - Effect of feeding system and ageing on lipid oxidation (TBARS, mg MDA/kg meat), protein oxidation (protein carbonyls, nmoles DNPH/mg protein) and SOD (IU/g meat), catalase (nmoles $\mathrm{H}_{2} \mathrm{O}_{2} / \mathrm{min} / \mathrm{mg}$ protein) and GPx (nmoles NADPH/min/mg protein) activities in LD muscle from Aberdeen Angus steers fed Pasture, Pasture plus grain supplementation $(\mathrm{P}+\mathrm{S})$ and Feedlot.

\begin{tabular}{|c|c|c|c|c|c|c|c|c|}
\hline & \multicolumn{3}{|c|}{ 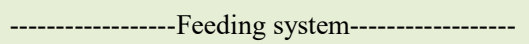 } & \multicolumn{2}{|c|}{--------------Ageing------------ } & \multicolumn{3}{|c|}{-------------Main Effects------------ } \\
\hline & Pasture & $\mathrm{P}+\mathrm{S}$ & Feedlot & Unaged & Aged & System (S) & Ageing (A) & $\mathrm{S}^{*} \mathrm{~A}$ \\
\hline TBARS & $0.46 \pm 0.05$ & $0.40 \pm 0.03$ & $0.35 \pm 0.04$ & $0.31 \pm 0.03 \mathrm{~B}$ & $0.48 \pm 0.03 \mathrm{~A}$ & NS & ${ }^{* * *}$ & NS \\
\hline Protein carbonyls & $0.30 \pm 0.03$ & $0.28 \pm 0.02$ & $0.31 \pm 0.03$ & $0.32 \pm 0.04$ & $0.27 \pm 0.02$ & NS & NS & NS \\
\hline SOD & $174 \pm 8 \mathrm{a}$ & $141 \pm 5 b$ & $175 \pm 4 \mathrm{a}$ & $177 \pm 6 \mathrm{~A}$ & $150 \pm 4 \mathrm{~B}$ & $* * * *$ & $* * * *$ & $*$ \\
\hline Catalase & $1518 \pm 106 a$ & $1165 \pm 117 b$ & $1180 \pm 87 \mathrm{~b}$ & $1296 \pm 94$ & $1280 \pm 87$ & ${ }^{*}$ & NS & $* * *$ \\
\hline GPx & $8.63 \pm 0.51 \mathrm{c}$ & $10.13 \pm 0.62 b$ & $10.68 \pm 0.20 \mathrm{a}$ & $10.45 \pm 0.46 \mathrm{~A}$ & $9.18 \pm 0.34 \mathrm{~B}$ & $* * * *$ & $* * *$ & NS \\
\hline
\end{tabular}

Values are means \pm SEM ( $=10)$. Different small letters in the same row show significant differences between feeding systems $(P<0.05)$ and different capital letters in the same row show significant differences between unaged and aged meat $(P<0.05)$. ${ }^{*} P<0.05 ;{ }^{* *} P<0.01$; ${ }^{* * *} P<0.001 ;{ }^{* * * *} P<0.0001$; NS: not significant $(P>0.05)$; $\mathrm{P}+\mathrm{S}$ : pasture plus grain supplementation. 
presented higher levels of TBARS compared with unaged meat. This increment of oxidation level with ageing was expected because lipid oxidation processes continue during the conservation of refrigerated and vacuum packaged meat. DESCALZO et al. (2008) also reported this result in buffalo LD aged 15 days. However, in another investigation from our laboratory (TEREVINTO, 2010), in the LD muscle from Hereford and Braford steers fed pasture, no increment of TBARS was observed after 14 days of refrigerated ageing in vacuum. Anyway, the increment of lipid oxidation levels observed in the present research, is largely below the suggested threshold of $2 \mathrm{mg}$ MDA/ $\mathrm{kg}$ meat that seems to cause rejection from consumers (CAMPO et al., 2006). No feeding system $\mathrm{x}$ ageing interaction was observed for lipid oxidation $(\mathrm{P}=0.70)$. When evaluating protein oxidation in LD muscle, no feeding effect was observed $(\mathrm{P}=0.74)$ (Table 1$)$. There are limited number of reports that compare protein oxidation process in meat through studies in different feeding conditions. This makes it difficult to discuss our results in comparison to others researches. No effect of ageing was observed on protein oxidation in the present research $(\mathrm{P}=0.07)$. In another investigation, TEREVINTO (2010) did not show an effect of ageing on the protein oxidation in LD muscle from Hereford and Braford steers fed pasture. No feeding system $\mathrm{x}$ ageing interaction was observed $(\mathrm{P}=0.68)$.

\section{Antioxidant enzymes activities}

A feeding effect was reported for SOD activity $(P<0.0001)$, where meat from Pasture and Feedlot presented a higher activity compared with meat from $P+S$ (Table 1). Other investigations reported that LD of Charolais steers (GATELLIER et al., 2004) and Charolais cows (MERCIER et al., 2004) fed on pasture had higher SOD activity than those fed concentrate. After ageing a significant effect was reported $(P<0.0001)$ for SOD, where aged meat had a lower activity than unaged meat. This decrease could be explained by a loss of activity due to the protein degradation that could occur during ageing (DAUN et al., 2001). In other research, a similar decrease in SOD activity with ageing was also seen in LD from Hereford steers produced in pasture (TEREVINTO, 2010). A feeding system $x$ ageing interaction was observed for SOD activity $(\mathrm{P}<0.05)$, (Table 1$)$.

With regards to catalase activity, a feeding effect was reported $(P<0.05)$ (Table 1), where meat from Pasture system presented a higher activity than meat from $P+S$ and Feedlot. No significant differences were reported between feeding systems (pasture vs grains) in the research of GATELLIER et al. (2004) and MERCIER at al. (2004) in Charolais LD muscle. Conversely, no ageing effect was observed for catalase activity $(\mathrm{P}=0.88)$ (Table 1$)$. A feeding system $\mathrm{x}$ ageing interaction was obtained $(\mathrm{P}<0.001)$.

When observing the results of GPx activity (Table 1), a feeding effect was reported $(P<0.0001)$ where meat from Feedlot presented a higher activity than meat from $P+S$; and meat from $P+S$ higher than meat from Pasture. Other authors (DESCALZO et al., 2000; GATELLIER et al., 2004; MERCIER et al., 2004; MOUTY et al., 2002) also observed a higher GPx activity in meat from animals produced with grains. Concerning this, GATELLIER et al. (2004) explained the higher activity in meat from steers fed grains partly because of the higher selenium content in this system compared with pasture, as Se is a cofactor of GPx. This explanation is not directly applicable to our results because a higher selenium content was reported in meat from Pasture system compared with Feedlot by SAADOUN \& CABRERA (2013), working with the same meat samples of the present study. An ageing effect was observed $(P<0.001)$, where aged meat presented a lower GPx activity than unaged meat and can be due to degradation of proteins during the ageing process (DAUN et al., 2001). In previous investigations, a decrease of GPx activities after meat ageing was also observed, in this case in Psoas major muscle, from Hereford and Braford steers fed pasture (TEREVINTO, 2010). No feeding system $x$ ageing interaction was observed $(\mathrm{P}=0.26)$.

\section{Antioxidant potential}

When antioxidant potential in LD muscle was evaluated by in vitro iron-induced lipid oxidation (Fenton Reaction), no feeding system effect was observed in unaged meat; however, in aged meat from steers produced with Pasture, lipid oxidation was lower compared with aged meat from Feedlot $(P<0.001)$ (Figure 1). Conversely, the response to induced oxidation of aged meat from animals produced in $P+S$ was not different from that produced with the other two feeding systems. At 120 min of incubation with iron and hydrogen peroxide, lipid oxidation levels were higher in aged meat from Feedlot compared with aged meat from the other two systems $(P<0.05)$.

Later, at $300 \mathrm{~min}$ of incubation, oxidation was higher in meat from Feedlot and $P+S$ compared with Pasture $(P<0.05)$. From these results we can conclude that aged LD from Aberdeen Angus steers produced with Pasture is more resistant to induced oxidation. The same result was also reported by MERCIER et al. (2004), in LD from Charolais cows, when comparing meat from animals finished with 


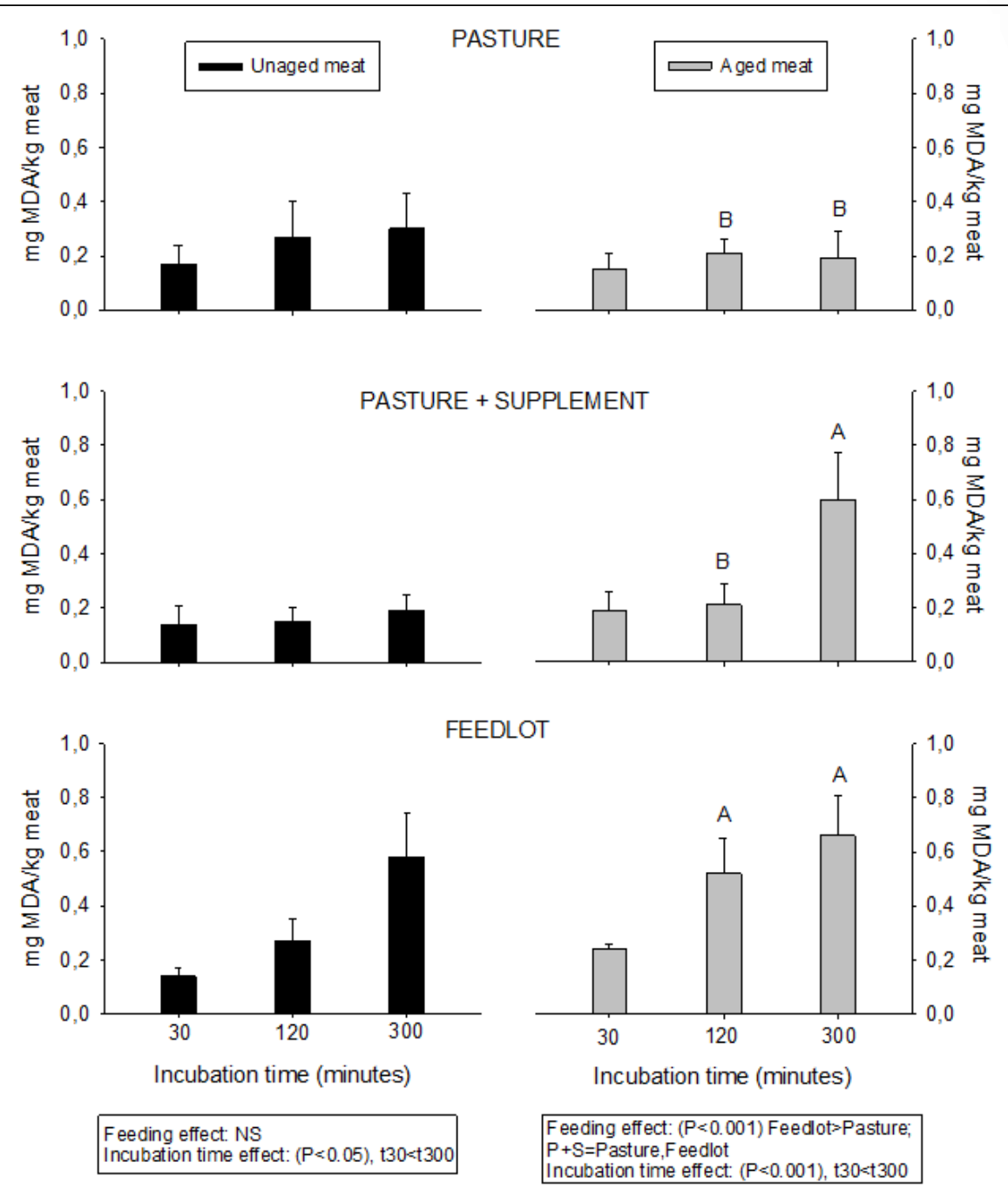

Figure 1 - Iron-induced lipid oxidation (TBARS, mg MDA/kg meat) in unaged and aged LD muscle from steers fed Pasture, Pasture plus grain supplementation and Feedlot. Bars are means \pm SEM ( $n=8)$. Different capital letters show significant differences between feeding systems in aged meat $(\mathrm{P}<0.05)$. $\mathrm{P}+\mathrm{S}$ : pasture plus grain supplementation.

grains and produced in pastures. This can be suggesting that beef meat from animals produced in pastures present a higher content of antioxidant compounds that come from fresh grass. In this sense, a higher content of $\alpha$-tocopherol and $\beta$-carotene was reported in meat from Aberdeen Angus steers produced in Pasture vs Feedlot in Uruguay (results not published). This is supported by several researches that reported a higher content of $\alpha$-tocopherol (DE LA FUENTE et al., 2009; DESCALZO et al., 2008; DESCALZO et al., 2005; HUMADA et al., 2014; INSANI et al. 2008; REALINI et al., 2004; YANG et al., 2002a) and $\beta$-carotene (DESCALZO et al., 2005; INSANI et al., 2008; SIMMONE et al., 1996; YANG et al., 2002a) in meat from animals fed pasture compared with those fed grains. Conversely, pasture fed animals tend to accumulate more omega- 3 fatty acids (DALEY et al., 2010; HUMADA et al., 2014), as reported in the present study, which are provided from pastures, and should make this type of meat more prone to lipid oxidation. But it seems that pro-oxidants/antioxidants balance favors the antioxidants. Another group of antioxidants that were measured in this study were the antioxidant enzymes, but results of their activity 
were not coincident. There was not a higher activity of the three enzymes in meat from Pasture system, so as to explain the higher antioxidant potential in this kind of meat. Finally, an incubation time effect was reported in unaged $(P<0.05)$ and aged meat $(P<0.001)$, where an increment of lipid oxidation levels can be seen from 30 until $300 \mathrm{~min}$. This increment with incubation time was also observed in unaged LD from Charolais cows (MERCIER et al., 2004) and Braford steers (TEREVINTO, 2010).

\section{Total lipids content and fatty acid composition}

A feeding system effect was observed for the intramuscular fat content in LD muscle $(P<0.001)$ (Table 2), where meat produced with Feedlot presented a higher (almost twice) lipid content compared to meat produced with Pasture and with $P+S$ feeding systems. This result was also reported by REALINI et al. (2004) in LD muscle from Hereford steers and GATELLIER et al. (2005) in LD muscle from Charolais steers, heifers and cows, when comparing pasture and grain systems. This is an expected result, because with a grain based diet and poor physical activity of animals in feedlot, they could deposit more fat than animals with a pasturebased diet and more physical activity (DALEY et al., 2010). This is a result favorable to meat produced in pasture because fat conscious consumers will prefer the overall lower fat content of a grass-fed beef product (DALEY et al., 2010).

Table 2 - Effect of feeding system on intramuscular fat content (\%) and fatty acid composition ( $\mathrm{g} / 100 \mathrm{~g}$ total fatty acids) of LD muscle from Aberdeen Angus steers fed Pasture, Pasture plus grain supplementation $(\mathrm{P}+\mathrm{S})$ and Feedlot.

\begin{tabular}{|c|c|c|c|c|}
\hline & Pasture & $\mathrm{P}+\mathrm{S}$ & Feedlot & $P$ \\
\hline$\%$ fat & $3.85 \pm 0.04 b$ & $4.09 \pm 0.65 b$ & $6.94 \pm 1.59 \mathrm{a}$ & $* * *$ \\
\hline C12:0 & $0.08 \pm 0.01$ & $0.08 \pm 0.02$ & $0.14 \pm 0.01$ & NS \\
\hline C14:0 & $2.57 \pm 0.97$ & $2.68 \pm 0.52$ & $4.16 \pm 0.25$ & NS \\
\hline $\mathrm{C} 15: 0 \mathrm{i}$ & $0.26 \pm 0.02$ & $0.32 \pm 0.04$ & $0.23 \pm 0.03$ & NS \\
\hline C15:0ai & $0.29 \pm 0.02$ & $0.33 \pm 0.05$ & $0.16 \pm 0.04$ & NS \\
\hline C14:1 & $0.32 \pm 0.03 b$ & $0.37 \pm 0.07 \mathrm{~b}$ & $0.75 \pm 0.07 \mathrm{a}$ & * \\
\hline $\mathrm{C} 15: 0$ & $0.65 \pm 0.03$ & $0.69 \pm 0.12$ & $0.55 \pm 0.05$ & NS \\
\hline $\mathrm{C} 16: 0 \mathrm{i}$ & $0.23 \pm 0.01$ & $0.20 \pm 0.03$ & $0.18 \pm 0.01$ & NS \\
\hline $\mathrm{C} 16: 0$ & $25.22 \pm 1.08 \mathrm{~b}$ & $25.77 \pm 1.72 b$ & $30.81 \pm 0.56 \mathrm{a}$ & ${ }^{*}$ \\
\hline C16:1 & $3.36 \pm 0.11 \mathrm{~b}$ & $3.40 \pm 0.23 \mathrm{~b}$ & $4.43 \pm 0.09 \mathrm{a}$ & * \\
\hline $\mathrm{C} 17: 0$ & $1.40 \pm 0.07 \mathrm{a}$ & $1.38 \pm 0.05 \mathrm{a}$ & $1.09 \pm 0.03 b$ & * \\
\hline $\mathrm{C} 17: 1$ & $0.99 \pm 0.02 \mathrm{a}$ & $0.96 \pm 0.07 \mathrm{a}$ & $0.71 \pm 0.01 \mathrm{~b}$ & * \\
\hline C18:0 & $18.53 \pm 0.40 \mathrm{a}$ & $18.61 \pm 1.08 \mathrm{a}$ & $13.53 \pm 0.34 b$ & ${ }^{*}$ \\
\hline C18:1 & $37.44 \pm 0.13$ & $37.65 \pm 1.13$ & $37.44 \pm 0.77$ & NS \\
\hline C18:2n-6 LA & $2.83 \pm 0.16$ & $2.49 \pm 0.29$ & $2.36 \pm 0.05$ & NS \\
\hline $\mathrm{C} 20: 0$ & $0.14 \pm 0.01$ & $0.13 \pm 0.04$ & $0.05 \pm 0.00$ & NS \\
\hline$C 18: 3 n-6$ & $0.02 \pm 0.00 \mathrm{~b}$ & $0.08 \pm 0.00 \mathrm{a}$ & $0.02 \pm 0.00 \mathrm{~b}$ & ${ }^{*}$ \\
\hline $\mathrm{C} 20: 1$ & $0.14 \pm 0.01$ & $0.12 \pm 0.01$ & $0.15 \pm 0.01$ & NS \\
\hline C18:3n-3 ALA & $0.57 \pm 0.01 \mathrm{~b}$ & $0.67 \pm 0.03 \mathrm{a}$ & $0.23 \pm 0.00 \mathrm{c}$ & ${ }^{*}$ \\
\hline CLA & $0.43 \pm 0.00$ & $0.42 \pm 0.06$ & $0.30 \pm 0.02$ & NS \\
\hline$C 20: 3 n-3$ & $0.09 \pm 0.00 \mathrm{a}$ & $0.11 \pm 0.01 \mathrm{a}$ & $0.03 \pm 0.00 \mathrm{~b}$ & ${ }^{*}$ \\
\hline$C 20: 3 n-6$ & $0.12 \pm 0.01 \mathrm{a}$ & $0.14 \pm 0.02 \mathrm{a}$ & $0.08 \pm 0.01 \mathrm{~b}$ & * \\
\hline C20:4n-6 ARA & $0.28 \pm 0.01$ & $0.32 \pm 0.06$ & $0.24 \pm 0.01$ & NS \\
\hline C20:5n-3 EPA & $0.06 \pm 0.01 \mathrm{a}$ & $0.08 \pm 0.01 \mathrm{a}$ & $0.02 \pm 0.00 \mathrm{~b}$ & ${ }^{*}$ \\
\hline C22:5n-3 DPA & $0.03 \pm 0.00$ & $0.05 \pm 0.01$ & $0.04 \pm 0.01$ & NS \\
\hline C22:6n-3 DHA & $0.21 \pm 0.01 \mathrm{a}$ & $0.26 \pm 0.04 \mathrm{a}$ & $0.08 \pm 0.01 \mathrm{~b}$ & * \\
\hline Unidentified & $3.76 \pm 0.81$ & $2.70 \pm 0.16$ & $2.23 \pm 0.18$ & $\ldots$ \\
\hline
\end{tabular}

Values are means $\pm \operatorname{SEM}(\mathrm{n}=10)$. Different letters within rows show significant difference between feeding systems $(P<0.05) .{ }^{*} P<0.05$; ${ }^{* *} P<0.01$; ${ }^{* * *} P<0.001$; NS: not significant $(P>0.05)$; $P$ : level of significance; i: iso; ai: anteiso; LA: linoleic acid; ALA: alfa-linolenic acid; CLA: isomer c9t11 of conjugated linoleic acid; ARA: arachidonic acid; EPA: eicosapentaenoic acid; DPA: docosapentaenoic acid; DHA: docosahexaenoic acid. 
When evaluating meat fatty acid composition, palmitic acid (C16:0) content was higher $(P<0.05)$ in LD from steers with Feedlot compared with the other two systems (Table 2). Another important saturated fatty acid, like stearic acid $(\mathrm{C} 18: 0)$, was higher $(P=0.01)$ in LD from Pasture and $P+S$ systems compared with Feedlot. In relation to other fatty acids, which have beneficial effects on consumers health, such as, oleic acid (C18:1), linoleic acid (C18:2n-6) and conjugated linoleic acid (CLA), no significant differences were observed between feeding systems. Despite this, EPA and DHA content was higher $(P=0.01$ and $P=0.02)$ in meat from Pasture and $P+S$ compared with Feedlot, and linolenic acid (C18:3n-3) content was higher $(P=0.01)$ in meat from $P+S$ compared with Pasture, and in meat from Pasture higher than in Feedlot.

\section{Health lipid indices}

In the present investigation, some lipid indices were calculated taking into consideration human health. These indices are generally used to rank foods in regard to their potential effect on the promotion of cardiovascular diseases (RAFIEIANKOPAEI et al., 2014). No significant differences were obtained between feeding systems in SFA, MUFA, PUFA and total n-6 fatty acids content (Table 3). Meat produced with Pasture alone or supplemented with grain, had a beneficial lower $n-6 / n-3$ ratio $(P=0.001)$, compared with meat produced in Feedlot. This is a positive aspect for consumers, as an excessive PUFA $n-6$ and an elevated n- $6 / n-3$ ratio, promote the occurrence of certain pathologies such as cardiovascular, cancer, inflammatory and autoimmune diseases (SIMOPOULOS, 2002). The difference reported between systems in $n-6 / n-3$ ratio, was explained by a higher content of n-3 fatty acids $(P=0.001)$ in meat from Pasture and $P+S$ compared to meat from Feedlot (DALEY et al., 2010). A higher $n-6 / n-3$ ratio was also reported in meat from grain based systems in other researches (DESCALZO et al., 2005; GARCÍA et al., 1999; YANG et al., 2002b). The mean n-6/n-3 ratio reported in LD muscle from Feedlot steers $(6.83 \pm 0.33)$ was higher than recommendations (4-5/1) by FAO-WHO (2010). As no difference was reported in PUFA and SFA content between systems, no difference was found in PUFA/SFA ratio in LD muscle. PUFA/SFA values in the three feeding systems were lower than recommendations $(0.45)$ by FAO-WHO (2010). The PUFA/SFA ratio is nowadays recommended to be above $0.4-0.5$ in order to prevent both, an excess of saturated fatty acids which affect negatively the LDL-cholesterol plasmatic level, and an excess of polyunsaturated fatty acids, some of them being precursors of powerful clotting agents and also being involved in the etiology of some cancers (STAJIC et al., 2011). Our results of fatty acid composition were in accordance to those reported in LD muscle from Charolais steers by GATELLIER et al. (2005).

With regards to the atherogenic index (AI), no differences were reported between feeding systems, but thrombogenic index (TI) was higher

Table 3 - Effect of feeding system on health lipid indices of LD muscle from Aberdeen Angus steers fed Pasture, Pasture plus grain supplementation $(\mathrm{P}+\mathrm{S})$ and Feedlot.

\begin{tabular}{|c|c|c|c|c|}
\hline & Pasture & $\mathrm{P}+\mathrm{S}$ & Feedlot & $P$ \\
\hline SFA & $49.37 \pm 1.38$ & $50.19 \pm 2.43$ & $50.91 \pm 0.90$ & NS \\
\hline MUFA & $42.25 \pm 0.01$ & $42.50 \pm 0.96$ & $43.48 \pm 0.63$ & NS \\
\hline PUFA & $4.63 \pm 0.17$ & $4.62 \pm 0.50$ & $3.39 \pm 0.09$ & NS \\
\hline$\Sigma \mathrm{n}-6$ & $3.24 \pm 0.18$ & $3.05 \pm 0.38$ & $2.70 \pm 0.06$ & NS \\
\hline$\Sigma \mathrm{n}-3$ & $0.96 \pm 0.01 \mathrm{a}$ & $1.15 \pm 0.1 \mathrm{a}$ & $0.40 \pm 0.02 \mathrm{~b}$ & ** \\
\hline$n-6 / n-3$ & $3.39 \pm 0.22 b$ & $2.63 \pm 0.12 b$ & $6.83 \pm 0.33 a$ & ** \\
\hline PUFA/SFA & $0.09 \pm 0.01$ & $0.09 \pm 0.02$ & $0.07 \pm 0.003$ & NS \\
\hline AI & $0.76 \pm 0.05$ & $0.78 \pm 0.11$ & $1.02 \pm 0.04$ & NS \\
\hline TI & $1.07 \pm 0.06 \mathrm{~b}$ & $1.08 \pm 0.12 b$ & $1.43 \pm 0.06 \mathrm{a}$ & ${ }^{*}$ \\
\hline $\mathrm{h} / \mathrm{H}$ & $1.69 \pm 0.05$ & $1.66 \pm 0.17$ & $1.34 \pm 0.05$ & NS \\
\hline
\end{tabular}

Values are means \pm SEM ( $\mathrm{n}=10)$. Different letters within rows show significant difference between feeding systems $(P<0.05) .{ }^{*} P<0.05$; ${ }^{* *} P<0.01$; NS: not significant $(P>0.05)$; $P$ : level of significance; SFA: saturated fatty acids; MUFA: monounsaturated fatty acids; PUFA: polyunsaturated fatty acids; AI: atherogenic index; TI: thrombogenic index; $\mathrm{h} / \mathrm{H}$ : hypocholesterolemic/hypercholesterolemic index. 
$(P<0.05)$ in LD from steers produced with Feedlot compared with the other two systems (Table 3). Having a higher TI means that it has a higher potential to form clots in blood vessels, which is harmful to consumers health (ULBRICHT \& SOUTHGATE, 1991). The hypocholesterolemic/ hypercholesterolemic index $(\mathrm{h} / \mathrm{H})$ must be as high as possible in order to protect consumers from the hypercholesterolaemia, a factor which promotes the atherosclerosis syndrome in humans (RAFIEIANKOPAEI et al., 2014). In the present research, this index was not significantly different in meat from the three systems (Table 3 ).

\section{CONCLUSION}

The LD muscle from Aberdeen Angus steers produced with pastures of Uruguay, is more resistant to induced oxidation, after suffering a process of ageing, than those produced with Feedlot system. Pasture system seems to generate a meat with higher catalase activity while Feedlot system produced a meat with higher GPx activity. Also, the obtained results support the idea that Aberdeen Angus steers finished with Pasture, even when they are grain supplemented, promote the production of a healthier meat for consumers, regarding the fatty acid composition and health lipid indices, in comparison to Feedlot system.

\section{ACKNOWLEDGEMENTS}

We would like to thank Alejandro Sans from Frigorífico Solís (BPU-NH group) and Ricardo Palma from the Uruguayan Society of Aberdeen Angus Breeders for their help. Also, to CSIC-Universidad de la República for the PhD scholarship given to Alejandra Terevinto.

\section{DECLARATION OF CONFLICT OF INTERESTS}

The authors declare no conflict of interest. The founding sponsors had no role in the design of the study; in the collection, analyses, or interpretation of data; in the writing of the manuscript, and in the decision to publish the results.

\section{AUTHORS' CONTRIBUTIONS}

Cabrera and Saadoun planned and designed the experiment, obtained the samples and supervised the work. Saadoun also performed the fatty acid analysis, calculated the health lipid indices and wrote part of the manuscript. Cabrera also provided advice on statistics. Terevinto carried out almost all the laboratory analysis, the statistical analysis of experimental data, performed the graphics and tables, and wrote almost all the manuscript. All authors critically revised the manuscript and approved of the final version.

\section{REFERENCES}

CABRERA, MC; SAADOUN, A. An overview of the nutritional value of beef and lamb meat from South America. Meat Science, v.98, p.435-444, 2014. Available from: <https:// www-sciencedirect-com.proxy.timbo.org.uy/science/article/pii/ S0309174014002010?via\%3Dihub>. Accessed: Apr. 24, 2019. doi: 10.1016/j.meatsci.2014.06.033.

CAMPO, $\mathrm{M}$ et al. Flavour perception of oxidation in beef. Meat Science, v.72, p.303-311, 2006. Available from: <https:// www-sciencedirect-com.proxy.timbo.org.uy/science/article/pii/ S0309174005003001?via\%3Dihub>. Accessed: May, 20, 2019. doi: 10.1016/j.meatsci.2005.07.015.

DALEY, CA et al. A review of fatty acid profiles and antioxidant content in grass-fed and grain-fed beef. Nutrition Journal, v.9, p.10, 2010. Available from: $<$ https://nutritionj.biomedcentral.com/ articles/10.1186/1475-2891-9-10>. Accessed: May, 20, 2019. doi: 10.1186/1475-2891-9-10.

DAUN, C et al. Glutathione peroxidase activity, tissue and soluble selenium content in beef and pork in relation to meat ageing and pig RN phenotype. Food Chemistry, v.73, p.313-319, 2001. Available from: <https://www-sciencedirect-com.proxy.timbo. org.uy/science/article/pii/S0308814600003034?via\%3Dihub>. Accessed: May, 20, 2019. doi: 10.1016/S0308-8146(00)00303-4.

DE LA FUENTE, $\mathrm{J}$ et al. Fatty acid and vitamin E composition of intramuscular fat in cattle reared in different production systems. Meat Science, v.82, supl. 3, p.331-337, 2009. Available from: $<$ https://www-sciencedirect-com.proxy.timbo.org.uy/science/ article/pii/S0309174009000424?via\%3Dihub>. Accessed: May, 20, 2019. doi: 10.1016/j.meatsci.2009.02.002.

DEL PUERTO, $M$ et al. A note on fatty acids profile of meat from broiler chickens supplemented with inorganic or organic selenium. International Journal of Food Science, 2017, p.1-8, 2017. Available from: <https:/www.hindawi.com/ journals/ijfs/2017/7613069/>. Accessed: Mar. 28, 2019. doi: $10.1155 / 2017 / 7613069$

DESCALZO, AM et al. Antioxidant consumption and development of oxidation during ageing of buffalo meat produced in Argentina. Meat Science, v.79, p.582-588, 2008. Available from: <https:// www-sciencedirect-com.proxy.timbo.org.uy/science/article/pii/ S0309174007003245?via\%3Dihub>. Accessed: Apr. 24, 2019. doi: 10.1016/j.meatsci.2007.10.020.

DESCALZO, AM et al. Influence of pasture or grain-based diets supplemented with vitamin $\mathrm{E}$ on antioxidant/oxidative balance of Argentine beef. Meat Science, v.70, p.35-44, 2005. Available from: <https://www-sciencedirect-com.proxy.timbo.org.uy/science/ article/pii/S0309174004003006?via\%3Dihub>. Accessed: Apr. 24, 2019. doi: 10.1016/j.meatsci.2004.11.018.

DESCALZO, AM et al. Antioxidant enzymes activity in Psoas major beef muscle from different production systems. In: International Congress of Meat Science and Technology, $46^{\text {th }}$, 2000, Buenos Aires, Argentina. Proceedings of the ICoMST, 4II, 2000. p.560-561. Available from: <http://icomst-proceedings. helsinki.fi/papers/2000_08_20.pdf>. Accessed: May, 20, 2019.

EDER, K. Gas chromatographic analysis of fatty acid methyl esters. Journal of Chromatography B: Biomedical Sciences and Applications, 671(1-2), p.113-131. 1995. Available from: < https:// 
www.sciencedirect.com/science/article/pii/0378434795001426> Accessed: Mar. 28, 2019. doi: 10.1016/0378-4347(95)00142-6.

FAO-WHO. Fats and fatty acids in human nutrition. Rome: FAO Food and nutrition paper \# 91. Report of an expert consultation. Geneva, November 10-14, 2010. Available from: <http://www.fao. org/3/a-i1953e.pdf $>$. Accessed: May, 20, 2019.

FERNÁNDEZ, M et al. Fatty acid compositions of selected varieties of Spanish dry ham related to their nutritional implications. Food Chemistry, v.101(1), p.107-112, 2006. Available from: <https:// www-sciencedirect-com.proxy.timbo.org.uy/science/article/pii/ S0308814606000513?via\%3Dihub>. Accessed: Mar. 28, 2019. doi: 10.1016/j.foodchem.2006.01.006.

FOLCH, $\mathrm{J}$ et al. A simple method for the isolation and purification of total lipid from animal tissues. Journal of Biological Chemistry, v.226, p.497-509, 1957. Available from: < http://www. jbc.org/content/226/1/497.long>. Accessed: Mar. 28, 2019.

GARCÍA, PT et al. Intramuscular fat, cholesterol and 18:2 n-6/18:3 n-3 ratio in total lipids in two frame steers under different dietary regimen. In: International Congress of Meat Science and Technology, 45 $5^{\text {th }}, 1999$, Yokohama, Japan. Proceedings of the ICoMST, 1999. p76-77. Available from: <http://icomst-proceedings.helsinki.fi/ papers/1999_02_12.pdf>. Accessed: May, 20, 2019.

GATELLIER, $P$ et al. Effect of finishing mode (pasture- or mixed diet) on lipid composition, colour stability and lipid oxidation in meat from Charolais cattle. Meat Science, v.69, p.175-186, 2005. Available from: <https://www-sciencedirect-com.proxy.timbo. org.uy/science/article/pii/S0309174004001755?via\%3Dihub> Accessed: May, 20, 2019. doi: 10.1016/j.meatsci.2004.06.022.

GATELLIER, $P$ et al. Effect of diet finishing mode (pasture or mixed diet) on antioxidant status of Charolais bovine meat. Meat Science, v.67, p.385-394, 2004. Available from: $<$ https://www. ncbi.nlm.nih.gov/pubmed/22061512>. Accessed: Apr. 24, 2019. doi: 10.1016/j.meatsci.2003.11.009.

HUMADA, MJ et al. Chemical composition, vitamin E content, lipid oxidation, color and cooking losses in meat from Tudanca bulls finished on semi-extensive or intensive systems and slaughtered at 12 or 14 months. Meat Science, v.96, p.908-915, 2014. Available from: <https://www-sciencedirect-com.proxy.timbo.org.uy/science/ article/pii/S0309174013005512?via\%3Dihub>. Accessed: May, 20 2019. doi: 10.1016/j.meatsci.2013.10.004.

ICHIHARA, $\mathrm{K}$ et al. An improved method for rapid analysis of the fatty acids of glycerolipids. Lipids, v.31, supl.5, p.535539, 1996. Available from: <https:/www.ncbi.nlm.nih.gov/ pubmed/8727647>. Accessed: Mar. 28, 2019. doi: 10.1007/ BF02522648.

INSANI, EM et al. Oxidative stability and its relationship with natural antioxidants during refrigerated display of beef produced in Argentina. Meat Science, v.79, p.444-452, 2008. Available from: $<$ https://www-sciencedirect-com.proxy.timbo.org.uy/science/ article/pii/S0309174007003191?via\%3Dihub>. Accessed: Apr. 24, 2019. doi: 10.1016/j.meatsci.2007.10.017.

LYNCH, SM; FREI, B. Mechanisms of copper- and iron-dependent oxidative modification of human low-density lipoprotein. Journa of Lipid Research, v.34, p.1745-1751, 1993. Available from: $<$ https://www.ncbi.nlm.nih.gov/pubmed/8245725>. Accessed: Mar. 28, 2019
MERCIER, $Y$ et al. Lipid and protein oxidation in vitro, and antioxidant potential in meat from Charolais cows finished on pasture or mixed diet. Meat Science, v.66, p.467-473, 2004. Available from: <https://www-sciencedirect-com.proxy.timbo. org.uy/science/article/pii/S0309174003001359?via\%3Dihub>. Accessed: Apr. 24, 2019. doi: 10.1016/S0309-1740(03)00135-9.

MOUTY, D et al. Lipoperoxidation et statut en antioxidants du plasma, du foie et des muscles de bouvillons engraissés avec un régime á base d'herbe. In: Rencontres Recherche Ruminants, 8 , 2002, Paris, France. Available from: <http://www.journees3r.fr/ IMG/pdf/2001_qualite_22_mouty.pdf>. Accessed: May, 20, 2019.

NCSS (STATISTICAL SOFTWARE), 2007. 329 North 1000 East, Kaysville, UT 84037, USA

RAFIEIAN-KOPAEI, M et al. Atherosclerosis: process, indicators, risk factors and new hopes. International Journal of Preventive Medicine, v.5, supl.8, p.927-946, 2014. Available from: <https://www.ncbi.nlm. nih.gov/pubmed/25489440>. Accessed: May, 20, 2019.

REALINI, CE et al. Effect of finishing diet on consumer acceptability of Uruguayan beef in the European market. Meat Science, v.81, p.499-506, 2009. Available from: <https:// www-sciencedirect-com.proxy.timbo.org.uy/science/article/pii/ S0309174008003367?via\%3Dihub>. Accessed: Apr. 24, 2019. doi: 10.1016/j.meatsci.2008.10.005.

REALINI, CE et al. Effect of pasture vs concentrate feeding with or without antioxidants on carcass characteristics, fatty acid composition, and quality of Uruguayan beef. Meat Science, v.66, p.567-577, 2004. Available from: <https:// www-sciencedirect-com.proxy.timbo.org.uy/science/article/pii/ S0309174003001608?via\%3Dihub>. Accessed: Apr. 24, 2019. doi: 10.1016/S0309-1740(03)00160-8.

SAADOUN, A; CABRERA, MC. Calidad nutricional de la carne bovina producida en Uruguay. Archivos Latinoamericanos de Producción Animal, v.21, supl.2, p.119-130, 2013. Available from: <http://www. produccion-animal.com.ar/informaciontecnica/carneysubproductos/161calidaduruguay.pdf $>$. Accessed: May, 20, 2019.

SIMMONE, $\mathrm{AH}$ et al. Consumer acceptability and $\beta$-carotene content of beef as related to cattle finishing diets. Journal of Food Science, v.61, supl.6, p.1254-1257, 1996. Available from: $<$ https:// onlinelibrary.wiley.com/doi/abs/10.1111/j.1365-2621.1996. tb10973.x>. Accessed: May, 20, 2019. doi: 10.1111/j.13652621.1996.tb10973.x.

SIMOPOULOS, AP. The importance of the ratio of omega-6/ omega-3 essential fatty acids. Biomedicine \& Pharmacotherapy, v.56, supl.8, p.365-379, 2002. Available from: $<$ https://wwwsciencedirect-com.proxy.timbo.org.uy/science/article/pii/ S0753332202002536?via\%3Dihub>. Accessed: Apr. 24, 2019. doi: 10.1016/S0753-3322(02)00253-6.

STAJIC, S et al. Cholesterol content and atherogenicity of fermented sausages made of pork meat from various breeds. Procedia Food Science, v.1, p.568-575, 2011. Available from: $<$ https://www-sciencedirect-com.proxy.timbo.org.uy/science/ article/pii/S2211601X11000873?via\%3Dihub>. Accessed: May, 20, 2019. doi: 10.1016/j.profoo.2011.09.086.

STOSCHECK, CM. Quantitation of Protein. Methods of Enzymology, v.182, p.50-68. 1990. Available from: <https:// www-sciencedirect-com.proxy.timbo.org.uy/science/article/pii/0 
07668799082008P?via\%3Dihub>. Accessed: Mar. 28, 2019. doi: 10.1016/0076-6879(90)82008-P.

TEREVINTO, A et al. Oxidative status, in vitro ironinduced lipid oxidation and superoxide dismutase, catalase and glutathione peroxidase activities in rhea meat. Meat Science, v.84, p.706-710, 2010. Available from: <https:// www-sciencedirect-com.proxy.timbo.org.uy/science/article/pii/ S0309174009003647?via\%3Dihub>. Accessed: Mar. 28, 2019. doi: 10.1016/j.meatsci.2009.11.007.
TEREVINTO, A. Oxidación lipídica y proteica, capacidad antioxidativa y actividad de las enzimas catalasa, superóxido dismutasa y glutatión peroxidasa en la carne fresca y madurada de novillos Hereford y Braford. Tesis de Maestría, Universidad de la República (Uruguay). Facultad de Agronomía. 2010. Available from: <https:// hdl.handle.net/20.500.12008/1815>. Accessed: May, 20, 2019.

ULBRICHT, TLV; SOUTHGATE, DA. Coronary heart disease: seven dietary factors. The Lancet, v.338, p.985-992, 1991. Available from: <http://eds.a.ebscohost.com.proxy.timbo.org. 